\title{
Weber eller Marx \\ - Om konstellationen mellem idealtyperne i protestantismetesen*
}

\author{
Jürgen Ritsert
}

Hvor ofte har man ikke set Max Webers 'protestantismetese' spillet ud mod Marx? Hvor stærkt vokser ikke bunken af de hver gang endegyldige beviser fra forskellige marxister for, at Weber skulle være en slem »idealist « eller $»$ bourgois «? Er den, som er ude efter den sande forskel i de to teoriers kerne og praktiske implikationer virkelig tjent med citater, hvoraf det skal fremgå, at kritikken af den politiske økonomi for længst en gang for alle har indset alt, også 'protestantismetesen'? »Kulten omkring pengene har sin askese, sin forsagelse, sin selvopofrelse - sparsommeligheden og beskedenheden, foragtelsen af de verdslige, temporære og forgængelige nydelser; jagten efter den evige skat. Deraf sammenhængen mellem den engelske puritanisme eller også den hollandske protestantisme med pengemageriet«. Marx, Grundrids, Kurasje/Modtryk 1974 s. 133). Lad os overlade disse pligtøvelser til dem, som opfatter dem som nyttige.

Jeg vil i første omgang blot gå ud fra en yderst simpel formodning: Weber og Marx forfølger - på hver sin forskellige måde - begge en række problemer, som hos begge to og deres tilhængere til dels fortsat består som problemer. Det forekommer mig, at det er problemstillinger af en sådan art, som ofte får etiketten 'struktur og subjekt'. Jeg vil med dette relationsproblem for $\varnothing$ je unders $\emptyset \mathrm{ge}$ en anden formodning lidt nærmere: I sin berømte studie »Den protestantiske etik og kapitalismens ånd $\aleph^{1}$ bearbejder Weber dette problem på en sådan måde, at han ikke blot som en mulighed, men meget ofte også i forhold til det han faktisk udtaler sig

\footnotetext{
* Artiklen er opstået som et led i et større arbejde med socialvidenskabernes socialhistorie, hvor bl.a. diskussionen af forholdet mellem Marx og Weber indgår. En uddybet metodologisk argumentation omkring de problemer, der rejses i forbindelse med den her offentliggjorte artikel om Den Protestantiske Etik findes i Ritsert, Sozialgesichte der Soziologie, Bericht: SoSo 1 Frankfurt/M Okt. 1980. 10. Den her bragte artikel om den protestantiske etik og idealtyperne er ikke offentliggjort før.

1. Jeg citerer efter flg. udgave: Max Weber, Gesammelte Aufsätze zur Religionssoziologie, Tübingen 1974. Som forkortelse for artiklen »Den protestantiske Ethik....«bruges PE. (Tallet efter skråstregen ved sideangivelser henviser til den danske oversættelse »Den protestantiske etik og kapitalismens ånd fra 1972. Denne udgave er udsolgt men findes i genoptryk udgivet af Gyldendals studiefakler 1981, 2. oplag Oslo. o.a.)
} 
om, beskæftiger sig med (må beskæftige sig med?) centrale motiver i den marxistiske teori. At registrere og rekonstruere dette kunne - omvendt måske også være en hjælp til den så ofte postulerede 'materialistiske teori om subjektet'.

Kapitalismens ånd fremstår hos Weber som historisk individ. Lige som f.eks. 'Bismarks politik' eller 'den middelalderlige kristendom' materialiserer den sig derfor som det til enhver tid konkrete resultat af en kulturvidenskabelig fremgangsmåde, som er kendetegnende for Weber, nemlig idealtypedannelsen. Den følger altså som resultat af et $\gg$ til værdier relateret « udvalg af sagsforhold i kulturvirkeligheden (»abstraktioner«), af udvalgte kendetegn, som er taget ud af deres sammenhæng og tilspidset for nogens vedkommende til tankemæssige grænsetilfælde (»pointeringer«), og sluttelig af indarbejdelsen af sådanne aspekter i tankebilledet, som slet intet modsvarer $\mathrm{i}$ virkeligheden (»idealisering «). I og med at det i forbindelse med kapitalismens ånd handler om et historisk individ, altså om »et kompleks af sammenhænge i den historiske virkelighed, som vi sammenfatter til et hele set ud fra deres kulturbetydning. «(PE 30/25), bliver vi på forhånd konfronteret med vanskelighederne i begreberne »kulturbetydning « og »værdirelatering « hos Weber. Selv det harmløse ord »vi« indeholder et problem. ${ }^{2}$

Et sted skriver Weber, at fænomener i den sociale virkelighed »tildeles« kulturbetydning »af os«. For forenklingens skyld bør »tildeling af kulturbetydning « måske splittes op i enkeltheder: Der eksisterer en proces, efter hvilken a) subjekter (»vi«), som anerkender b) bestemte »værdier « som forpligtende, c) på grund af netop denne orientering mod værdier kun skænker bestemte genstande og kendetegn tankemæssig opmærksomhed og hensyn i

2. Se omkring dette problem mere udførligt: J. Ritsert, »Wertbeziehung « to the societal basis - Two lines of argument in Marx Webers theory of action? in: L. Nowak (ed) Social Classes, Action and Historical materialism, Amsterdam 1982.

Fra denne artikel har Kurasje klippet følgende:

»Hele processen, hvor vidensobjektet konstitueres eller videnskabelig indsigt i virkeligheden opnås under styring af værdier, blev af Weber kaldet »værdirelatering « (Wertbeziehung). At sætte aspekter af det virkelige i relation til værdier, giver betydning til virkeligheden, elementer af virkeligheden får »kulturbetydning « (Kulturbedeutung) eller kulturel betydning.« For os er den empiriske virkelighed 'kultur' fordi og for så vidt vi sætter den i forbindelse med værdier; den opfatter de og kun de dele af virkeligheden, som betydningsfuld for os som følge af denne forbindelse.« ... At relatere aspekter af virkeligheden til værdier betyder at give kulturel betydning (kulturbetydning) til disse elementer eller lag. Med andre ord: ledet af værdier udvælger vi specielle punkter af den uendelige mangfoldighed af historiske karakteristika og relationer, og sammensætter eller komponerer dem succesivt til et »historisk individ « - det vil sige: et »kompleks af forbindelser i den historiske virkelighed som vi begrebsmæssigt forener til et hele under synsvinklen, deres kulturelle perspektiv.« 
adfærden. For så vidt denne selektivitet d) bliver styret af orienteringen mod samfundsmæssigt (kulturelt) alment gældende værdier (»Kulturværdier«) er noget »kulturbetydningsfuldt « for den. ${ }^{3}$

Når kulturværdiideerne c) leder frem til den værdirelaterede konstitution af erfaringsobjekter ud af »begivenhedernes kaotiske mangfoldighed « og vejleder forskernes og forskersamfundets idealtypedannelse, har disse ideer funktion af »erkendelsesinteresse«. Disse »værdiideer « gælder ikke bare som målestok for vurderinger, men de omfatter også normer, handlingsregler, planer, mål, hensigter, mønstre for vurdering af situationer (f.eks. verdensbilleder). Og den »empiriske virkelighed bliver 'kultur' for os, fordi og for så vidt $v i$ sætter den i relation til værdiideer... $\ll^{4}$. Men hvem er »vi«, som vi yder denne ejendommelige præstation for? For det første sikkert videnskabsmænd, som har dannet en indbyrdes sammenlignelig erkendelsesinteresse gennem orienteringen mod fælles »kulturværdier«. I lyset af deres erkendelsesinteresser hæver de alle sådanne genstande og kendetegn op fra den uendelige mangfoldighed af faktiske begivenheder, som så kan indgå som »momenter« i den ligeledes værdirelaterede »komposition « (Weber) af en idealtype. For det andet er der også tale om »vi« som hverdagsmennesker, hvis værdirelationer ligeledes hjælper med til at give betydning (for os) til bestanddele fra en kaotisk fremtrædelses- og begivenhedsrigdom. Anskuet således er det nok heller ikke noget tilfælde, når Weber taler om »de værdiideer, som behersker...forskerne og deres tid $\aleph^{5}$ Kulturvirkelighed kommer ikke mindst istand gennem værdirelatering blandt mennesker i hverdagsverdenen.

Efter min opfattelse må man tage denne dobbelttydighed i betragtning, når man spørger efter det stof, som typen »kapitalismens ånd «skal sammenføjes af. Den sammensættes af en mangfoldighed af handlings- og holdningsregler, værdimålestokke, moralske anbefalinger og forpligtelser, ideer, utopier, opfattelser, som i selve kulturvirkeligheden, dvs. hos »os « som hverdagsmennesker i et bestemt historisk tidsafsnit, er eller har været i omløb. For

3. Den empiriske virkelighed er »kultur« for os, når og for så vidt vi sætter den i relation til værdiideer, den omfatter sådanne bestanddele af virkeligheden, som gennem denne relationibliver betydningsfulde for os, og kun sådanne. En ubetydeligt del af den til en hver tid betragtede individuelle virkelighed, farves af vores interesser, som er betingede af sådanne værdiideer; kun denne lille del har betydning for os og det har den, fordi den henviser til betingelser, som er vigtige for os som følge af dens sammenknytning med værdiideer« M. Weber, Die »Objektivität« sozialwissenschaftlicher und sozialpolitischer Erkenntniss, in: Gesammelte Aufsätze zur Wissenschaftslehre, Tübingen 1943, p. 28.

4. Om det weberske virkelighedsbegrebs dobbeltkarakter se 'Wertbeziehung' to societal.... op.cit.

5. M. Weber Die »Objektivität«... op.cit. p. 184. 
så vidt hører de til en kulturvirkelighed, som altid allerede er konstitueret gennem de handlende subjekter orienteringer. »Vi« som historiker eller socialvidenskabsmand står overfor den opgave at skabe en komposition af idealtyper af dette stof. $\mathrm{Da} » v i$ i det weberske projekt er beskæftiget med aspekter og elementer i en økonomisk etos, den kapitalistiske, må egentlig alle de af hverdagsagenternes »ideer « komme i centrum for opmærksomheden, hvis meningsindhold udtrykker hhv. betyder noget fra produktionens, fordelingens og konsumtionens område, eller står i en empirisk relation til sagsforhold indenfor disse områder. Anskuet således skulle den weberske kulturvidenskab faktisk være beskæftiget med »det økonomiske hverdagslivs maximer «(PE 163/96). Det historiske spring i den tid, hvor den vestlige kapitalisme opstår, tillader imidlertid ikke en sådan direkte tilgang. Weber vælger derfor som første takt i kompositionen af sin idealtype »kapitalismens ånd « et dokument om hvilket han antager, at det allerede indeholder den kapitalistiske $\varnothing$ konomiske tænkemåde i »omtrent klassisk renhed « (PE 31/26): Benjamin Franklins »Retningslinier for en ung handelsmand « fra 1748.

Franklins forsvarstale for selvkontrol, tidsøkonomi, ærefrygt for pengenes produktivitet, sparsommelighed, mådeholdenhed, ordenssans, men først og fremmest for arbejdsflid, tilbyder mere end blot tommelfingerregler til imødegåelse af økonomiske vanskeligheder. Det der lå ham på sinde var et etos, ikke blot en livsteknik, en kapitalistisk tænkemåde og sindelag, ikke et regelsæt for forretningsfolk. Denne etos viser personens hele livsførelse vejen, og forsyndelser mod dens principper betyder pligtforsømmelse ikke blot uduelighed. Det ligger i hele det weberske projekts logik, at man skulle videreudbygge det hos Franklins nærmest idealtypisk foreliggende udtryk for kapitalistisk tænkemåde og sammenføje det til en virkelig ren type. En sådan er nødvendig for at kunne gennemtrænge og samtidig forstå mangfoldigheden i kulturvirkelighedens processer, skønt hverdagsmenneskene på deres side allerede - f.eks. når de vælger bestemte muligheder og udelukker andre - gennem »værdirelatering « har frembragt $»$ kulturbetydning «.

Men hos Weber hører det også til begrebet »kulturbetydning « at værdirelationer ikke blot leder enkelte få personers orientering, men først antager skikkelse af en betydningsfuld »anskuelsesmåde «, når de bliver båret af bredere menneskegrupper. Altså kunne en ren kapitalistisk tænkemådes idealtype også hjælpe til med at finde frem til hvorvidt denne ånd var fremherskende indenfor bestemte områder af kulturvirkeligheden, måske sågar indenfor bestemte klasser, grupper og sammenslutninger. Man kan følgelig tale om »fremhersken«, når der hos specifikke bærergrupper kan 
konstateres en tilnærmelse til det rene billede. På forskellige steder går argumenterne i denne retning. Således f.eks. når Weber til overvejelse anfører, at det på tærsklen til den ny tid på ingen måde var de »kapitalistiske foretagere blandt handelspatricierne, men derimod langt mere de opadstræbende grupper fra den håndværksmæssige middelstand, der (var) bærere af den tænkemåde, som vi her har betegnet som 'kapitalismens ånd'." (PE 49/37). Alligevel er graden af den kapitalistiske etos' fremhersken ikke den for Weber afgørende problemstilling. I centrum for hans unders $\emptyset$ gelse står som bekendt problemet om betingelserne for den kapitalistiske ånds tilblivelse. Men hvordan kom han frem til, at »denne tilblivelse er det som egentlig skal forklares « (PE 37/30); det er det den overvejende del af Webers udredning i virkeligheden koncentrerer sig om. Det er ikke hensigten med min fremstilling at følge udredningen i enkeltheder og endnu engang vurdere den. Jeg forholder mig kun til Webers forklaringsstrategi for så vidt den lader sig udbygge, eller helt igennem ombygge til en konstellation af idealtyper, som kan tjene til en mere tilspidset udgave af mine to udgangsspørgsmål:

1. Forbliver Weber med sin protestantismetese nødvendigvis en ren overbygningsteoretiker?

2. Hvor langt kommer han i den også for marxister problematiske bestemmelse af forholdet mellem socialstruktur og subjektivitet?

Weber spørger her - idet han tager et helt andet udgangspunkt end Marx - ikke først efter hvilke økonomiske interesser, kampe, magtudfoldelser, der ligger bag, hvad de klassiske nationaløkonomer har kaldt »den oprindelige akkumulation«. Det drejer sig for ham ikke om oprindelsen af kapitalistiske pengeophobninger, som kan værdiøges (jvf. PE 52 f/39), men om en etos, som udvikler sig, senere udbredes og når frem til at blive den fremherskende. Webers berømte svar på spørgsmålet om kapitalismens opståen koncentrerer sig om den protestantiske religion i almenhed, den asketiske protestantisme i særdeleshed. (jvf. PE 84 ff./57 ff). Hvorfor nu gå tilbage til religionen? Den tidlige kapitalisme opstår naturligvis i en tid, hvor religiøst indhold et langt stykke har et fast greb om en afgørende del af de personlige motiver, af verdens- og selvforståelsen hos de fleste mennesker.

Den kapitalistiske ånd kunne under de daværende betingelser naturligvis ikke bare træde frem i sækulære former. Når det samtidig ikke er muligt at gribe direkte fat i hverdagssproglige orienteringer, så byder til gengæld de skrevne moral- og trosartikler såvel som teologiske doktriner sig til som udgangspunkt. I disse måtte det kunne lade sig aflæse, hvilke af de tænkemåder, som var sammenhængende med økonomien, der 
dengang fik tildelt en religiøs præmie, og hvilke der ikke fik det. Og trosog kulturkampene drejede sig nu engang på det tidspunkt, dvs. i det 16. og 17. århundrede, i de »kapitalistisk mest fremskredne lande « (Nederlandene, England og delvis også Frankrig) om Calvinismen og dens varianter.

I følge Weber var det hos dens tilhængere, at kombinationen af en virtuos kapitalistisk forretningssans og »en fromhed, som gennemtrængte og regulerede hele livet « (PE 26/22) mest tydeligt kom frem. Dér blev på det mest eftertrykkelige udlovet frelse som præmie for en systematisk kontrolleret livsførelse og erhvervsmæssig foretagsomhed. I første omgang må det undre, fordi Calvin hældede til en streng skæbnetro (prædestinationslære), som koblede fordømmelse og frelse til Guds oprindelige afgørelse uden nogen chance for individuel indblanding. Men for de troende var det sjæleligt nærmest uudholdeligt, at de overhovedet ikke havde noget holdepunkt i det jordiske liv for, hvor de stod i forhold til nåden. I den teologiske opfattelse på daværende tidspunkt satte det sig da også mere og mere igennem, at skønt de jordiske handlinger ikke kunne være et virksomt middel til at nå den himmelske tilstand, så kunne de jordiske handlinger i det mindste være et tegn på udvalgtheden. (PE 110/69). Gud hjælper den, som hjælper sig selv, den som holder sig selv i tugt, den som skaber sig visheden om sin udvalgthed (PE 111/70). Den troende måtte altså blot bestræbe sig på at finde og genfinde holdepunkter for nådesvalget i sit virke. Er det daglige virke til Guds ære ikke nogen realgrund for nådestildelingen, så vinder det dog tiltagende tilforladelighed som erkendelsesgrundlag (PE 147/86). Således tilskyndet af de religiøse doktriner til bestandig at agte på sig selv og konsekvenserne af sine handlinger og dermed på betingelserne for sin frelse, forstærkes hos både enfoldige og mere sofistikerede troende motivet til selvkontrol, disciplin og travl foretagsomhed. Dette udfolder sig som personlige indstillinger, foretagsomheden bliver et kald, en personlig pligt. »Reformationens effekt som sådan var i første række kun - i kontrast til den katolske opfattelse - at den moralske accent og den religiøse præmiering for dennesidige, verdslige erhvervsmæssigt indrettede arbejde svulmede voldsomt op« (PE 74/48). Det daglige erhvervsarbejde blev, formidlet over den betydning religionen havde for den enkelte, så at sige indplantet i protestanternes og de reformertes tænkemåder og sindelag.

Naturligvis gjaldt arbejdet, virket, også allerede før reformationen som et afgørende middel til asketisk livsførelse. Arbejdet skulle beskytte mod udskejelser, forsømmelighed i luxus og moralsk forfald. Men efter Webers afgørende tese bliver arbejdet i og med den protestantiske etik til et mål i sig selv forankret i det enkelte subjekts motivstruktur. (PE 171/98), og 
dermed får den verdslige succes, i sidste ende det rastløst sammenbragte og sparsommeligt sikrede udbytte, en særlig hellighed. Det betyder altsammen imidlertid også en afgørende religiøs støtte til den enkelte, som i modsætning til, hvad der var tilfældet med den tidligere skatteophobningsimpuls, oplever pligtens etiske hellighed. Kort sagt: Protestantismen støtter den denne sidige askese og følgelig alle de tænkemåder, som giver den kapitalistiske ånd styrke til at sive ud og brede sig i hverdagslivet. »Den dennesidige protestantiske askese - således kan vi godt sammenfatte det hidtil sagte - virkede altså med fuld kraft mod den ugernerte nydelse af besiddelsen, den indsnævrede konsumtionen, især luxuskonsumtionen. Derimod befriede den i sin psykologiske effekt erhvervelsen af goder fra den traditionalistiske etiks hæmninger, den sprængte lænkerne, der var lagt på stræben efter gevinst, idet den ikke blot legaliserede, men (i den her fremstillede forstand) direkte anså denne stræben for at være villet af Gud « (PE 190/106).

Selv denne knappe skitse af den weberske argumentationsgang tydeliggør nogle problemer, som hidrører fra den indledningsvist beskrevne dobbelttydighed i hans lære om »kulturbetydning «: Også Weber kan naturligvis kun i meget ringe udstrækning forlade sig på materiale, som umiddelbart stammer fra hverdagsverdenen. Han komponerer ikke i nævneværdig grad sin idealtype 'den kapitalistiske ånd' på hverdagsorienteringerne hos grupper af bærere af sådanne forestillinger, men på teologiske skrifter fra Calvin, Luther, Baxter, Franklin og andre. Den tese som bestandig kommer til syne hos ham, at han hermed har fået fat om det afgørende i en ånd, som i det mindste var fremherskende blandt grupperinger i den sociale virkelighed, må bero på den overvejelse, at den protestantiske teologi har formuleret anskuelser, som »vi« som troende i den daværende periode mere eller mindre eftertrykkeligt har tilpasset os. Det er nok problemet for enhver unders $\varnothing$ gelse, som retter sig ind mod historiske social-karakterer. Et specifikt problem opstår ganske vist af karakteren af og den metodiske stringens i de idealtyper, som Weber betjener sig af til udvikling af protestantismetesen. Er f.eks. »lutherdommen«, »calvinismen «, »metodismen« etc. enkelte idealtyper, som igen indgår som elementer i konstruktionen af den omfattende type »asketisk protestantisme «? Er den »asketiske protestantisme « et særligt historisk individ, den »kapitalistiske ånd « et andet, hvis opståen skal forklares ud fra det første? Jeg vil ikke gå ind på disse spørgsmål, men går ud fra den harmløse opfattelse, at den »asketiske protestantisme « hos Weber er en for-form eller tidlig form af den kapitalistiske ånd selv; på en måde dens kimcelle! Følgelig må det så være tilladt at begribe disse oprindelses- 
former for kapitalismens ånd som dén idealtype, som behersker Webers værk $^{6}$. For mig drejer det sig nemlig i det følgende om to andre typer, som hos Weber lever et gedulgt og alligevel mærkbart liv.

Forstår vi et »historisk individ « som resultatet af en idealtypiserende konstruktion, der tydes $i$ dens forhold til kulturvirkeligheden, så kan man begribe »den traditionalistiske etik « (PE 190/106) eller den »(katolske) traditionalisme« som modtypen til den asketiske protestantisme. Dette historiske individ omfatter karaktertræk fra den middelalderlig-katolske religiøsitet og dennes tilsvarende livsstil. Weber har ikke udarbejdet denne type på en lige så klar og detailleret måde som den »kapitalistiske ånd « $\mathrm{i}$ dennes tidlige form, men i teksten findes der hele tiden henvisninger til enkelte af dens bestanddele og disses forhold til de $\varnothing$ konomiske handlingsmønstre. Hvis man komponerede de spredte henvisninger til traditionalismen idealtypisk sammen, ville der fremkomme et billede af førkapitalistiske livsanskuelser. Funktionen af en sådan konstruktion er klar: Den tjener Weber som en slags kontrastbaggrund, som negation eller modpol i forhold til afgørende aspekter af den kapitalistiske ånd, således at dennes historiske ejendommeligheder træder tydeligere frem. Det kanoniserede renteforbud til forskel fra den protestantisk præmierede fortjeneste-tænkemåde står som klassisk eksempel på sådanne modsætninger. Eksempler som dette hjælper til at afgrænse den ene betydningsfulde kulturfremtrædelse »i dens individuelle egenart« (PE 30/25) fra den anden. Til forskel f.eks. fra den strenghed i livsførelsen, som protestantismen forlanger af den enkelte, til forskel altså fra dennes »uendelig tyngende og alvorsprægede reglementering af hele livsførelsen, der gik så vidt som tænkes kunne inden for alle sfærer af det private og offentlige liv »(PE 20/18), forholder katolicismen sig strengt mod kætteren, men ikke mod synderen. Denne kan gøre bod, gøre afbigt eller frikøbe sig fra skærsilden (jvf. PE 59/43, 113/71). I den middelalderlige kultur, som beherskedes af den katolske etos, fandtes den bedriftsmæssigt rationelle organisation af det daglige liv ikke i nævneværdigt omfang. Virke fremtræder i et andet lys. Erhvervsbeskæftigelse er hverken en gudsbestemt pligt eller et kald til handlen, der forøgede indsatsen og fortjenesten. Således ansporede f.eks. merfortjenesten ikke arbejderen så meget som »det at arbejde mindre; han spurgte ikke: hvor meget kan jeg tjene om dagen, hvis jeg yder det mulige maksimum af arbejde, men hvor meget må jeg arbejde for at tjene det beløb, som jeg hidtil fik og som dækker mine traditionelle

6. Også selv om det måtte være svært at påvise, at denne ene idealtype er produktet af en strikt anvendelse af Webers metodologi. 
behov?« (PE 44/33). Sombart og andre konfronterer derfor det middelalderlige princip om dækningen af et ordnet behov, »næringen «, med det kapitalistiske princip om den rationelt organiserede fortjenestes $\emptyset$ gning. For det middelalderlige menneske, der følger den katolske traditionalismes maximer, måtte det faktisk forekomme som en vej til fordømmelse at indrette sit liv på puklen og skraben-til-sig for »engang at synke i graven belastet med en stor materiel vægt af penge og goder « (PE 55/44). Det er altså ikke blot en teologisk strid, men en forandring af dybtsiddende tænkemåder, der står bag vendingen mod traditionalismen. Diskussionerne førte i en retning, hvor det lykkedes brede befolkningsgrupper »at omforme arbejdsopfattelsen til en følelse af erhvervspligt, arbejdet til et mål i sig selv«. Havde middelalderen endnu opfattet almisserne som en pligt, tiggerne ofte som en særlig stand (PE 199/110), så tvinger de tidlige kapitalister rodløse, fordrevne, tiggere og vagabonder ind i fattig- og arbejdshusene, i sidste ende ind i fabrikkerne.

Også askesens art er grundforskellig. Det denne-sidige i protestantismen står overfor det hinsidige i traditionalismen. Middelalderens munk var jo også på sin måde indstillet mod en metodisk livsførelse; bederitualernes tidstakt pålagde også hans dagsforløb en disciplin. Desuden har klostrene allerede længe før protestanterne dyrket arbejde som et middel til askese. »Det afgørende var imidlertid: at det i religiøs henseende metodisk levende menneske par excellence netop alene var og blev munken, at altså askesen jo mere intensivt den greb den enkelte desto mere trængte ham $u d$ af hverdagslivet, fordi det specifikt hellige netop lå i overbydelsen af den verdslige sædelighed «(PE 119/73). Denne forskel mellem den verdslige, i den borgerlige hverdag praktiserede askese og den munkelige asketisme, hvor munken - i det mindste i den idealtypiske rekonstruktion af munkens livsregler - trækker sig ud af dagsværket og erhvervsarbejdet, udgør en af de modsætninger, som Weber søger at afdække i konfrontationen mellem »kapitalistisk ånd « og »traditionalistisk etos«. Kort sagt: Weber arbejder i første omgang med to overbygningstyper, med to typiseringer af historisk kulturbetydende etikker. Den hovedrelation, som han afdækker mellem dem, er den delvis til modsætning tilspidsede forskel. Samtidig sætter han de to typer $\mathrm{i}$ et forhold af historisk følgen efter hinanden, også selvom begge tænkemåder eksisterer videre ved siden af hinanden og overlejrer hinanden i den kapitalistiske nyere tid. Weber insisterer imidlertid på den sluttelige gennemsatning (»fremhersken«) af den kapitalistiske ånd overfor den katolske traditionalisme.

De to overbygningstyper skal ikke - trods en nærliggende fordom herom forstås som statiske typiseringer i betydningen indoptagelse af historiske 
momenter. De indeholder hele tiden antagelser omkring betingelserne for deres forandring og udvikling. Således bliver der f.eks. omkring typen »kapitalismens ånd « på forskellige steder henvist til ændringer i bærergruppens motivationsbasis som grund til afslibningen af Calvins strenge prædestinationslære. Calvinisternes ganske menneskelige behov for i det mindste at finde anknytningspunkter for hvor de stod i forhold til nåden, kunne religionen ikke modstå i længden. Det gav på sin side indvirken på de kaldsforestillinger, som er kendetegnende for den kapitalistiske ånd. Webers idealtyper er altså på ingen måde blottet for en indre historicitet.

Alligevel tror jeg ikke, at det er tilstrækkeligt, at hænge den weberske protestantismetese op alene på konstellationen af disse to overbygningstyper eller deres underopdelinger. I det mindste må en tredie stor type drages frem som gedulgt argumentationsgrundlag. Denne resulterer imidlertid ikke som en komposition af elementer fra aktørernes betydnings- og situationsforståelse (hhv. fra teologiske indikatorer) i en etos, en ånd, men fører til et udtryk for socialstrukturelle kendsgerninger i kapitalismen, som ikke kan føres tilbage til betydningsindhold. M.a.o.: Det ville være en fejl, omend nærliggende, at antage, at Weber alene skulle udvikle sine overvejelser om kapitalismens opståen i forhold til træk fra en bestemt $\varnothing$ konomisk tænkemåde. Hans begreb om »kapitalismen« indeholder videregående konnotationer. Den skal hos ham forstås som et historisk individ, der ikke kun er konstitueret over den specifikke mening (Sinn), som et betydeligt antal menneskers handlinger måtte være orienteret efter. Hvis man ikke - som det sker hos mange systemteoretikere - på tautologisk vis sætter »mening « lig med selve det, at noget er organiseret eller lig med organiserende processer i sociale systemer i det hele taget, så tager også Weber implicit hensyn til kapitalismens side af faktisk (materiel), socialstrukturel sammenfatning, og selvom denne strukturtype også kun optræder sporadisk i teksten, så fremgår dens elementer tydeligt nok i forbemærkningen til bogen (PE 1-16/3-13): Kapitalismen skal forstås som et særligt system, der kendetegner en bestemt epoke af den vestlige udvikling. Uden tvivl er den også lige så afhængig af en specifik etos', en specifik ånds, gennemsætning som af grundfæstningen af helt bestemte motiver hos dens agenter, f.eks. den stadige stræben efter ny gevinst, stadig voksende rentabilitet og beredskab til konkurrenceadfærd (PE 4/5-6).

Men denne samfundsmæssige helhed udgør en sammenhæng, hvis ordningsprincipper også sagtens kan influere på de enkelte subjekters aktivitet samt selv- og verdensforståelse. »Indenfor en kapitalistisk ordning af den samlede økonomi ville en kapitalistisk enkeltvirksomhed, som ikke orienterer sig mod chancen for rentabilitetsopnåelse, være dømt til 
undergang (PE 4/6). Der findes lovlignende sammenhænge mellem strukturbetydningsfulde enkeltforhold og -foreteelser. »Lovlignende" skal her ikke forstås via det nomologiske lovbegreb, men betyder begivenhedsfølger, som gentager sig i et tidsafsnit, - kapitalistisk reproduktion. »Strukturbetydningsfuld « kan forstås som pendent til »kulturbetydningsfuld « og skal således udtrykke en enkeltheds funktion og rolle i reproduktionskredsløbet: Der rejser sig dermed det spørgsmål, hvilke aspekter af den mangfoldige kapitalistiske virkelighed der må fremhæves, hvilke abstraktioner, pointeringer og idealiseringer der må foretages for at finde et idealtypisk udtryk for lovmæssighed(er) og strukturbetydningsfulde fænomener i kapitalismen som system. Webers bestemmelsesfors $\emptyset \mathrm{g}$ kommer i dette tilfælde forbavsende tæt på Marx'; thi også for Weber har den »rationel-kapitalistiske organisation af (formelt) frit arbejde « (PE 7/8) kernestrukturel betydning i det historiske system »kapitalisme«. Vi ser et $\varnothing$ jeblik bort fra princippet om det rationelle, som utvivlsomt spiller en for Weber lige så karakteristisk som afgørende rolle i forsøget på at afgrænse den vesterlandske, »intet andetsteds udviklede form for kapitalisme « (sammesteds). Med samme eftertryk henviser han nemlig til det »formelt frie arbejde «s strukturbetydning. Formelt fri er lønarbejdet i forholdet til kapitalen. Kort sagt: I alle andre sociale systemer, som nok kender til stræben efter fortjenester, guld- og pengebegær, udbytning af arbejde, ekspanderende spekulations-, handels og finansinteresser, »mangler den moderne modsætning: storindustrielle driftsherrer og frie lønarbejdere « (PE 9). Også »adskillelsen af husholdning og virksomhed «, som hele tiden fremhæves af Weber og de fleste moderne lærebøger i økonomi, er heller ikke andet end et udtryk for dét kapitalistiske arrangement på den ene side at overlade den »frie « vare arbejdskraft til virksomhedsejerens og -lederens kommando i produktionen, mens »husholdningen « på den anden side skal udgøre stedet for de afhængiges og de selvstændiges forbrug af penge og goder. Betragtet efter dens strukturelt organiserende principper, som strukturtype, er den moderne kapitalisme også hos Weber ikke meget andet end »borgerlig virksomhedskapitalisme med dens rationelle organisation af det friearbejde" (PE 10/10). Et andet sted (PE 9/10) sættes kalkulerbarheden sågar efter arbejdskraftens bliven-til-vare. En eksakt virksomhedskalkulation, hedder det, er overhovedet kun mulig på grundlag af frit arbejde.

En drejning af den weberske argumentation, der retter sig imod Marx, når imidlertid også hermed sin yderste grænse. Thi den sædvanlige weberske relatering til kulturværdier blandes hele tiden sammen med konstitutionen af en ren strukturtype. I tilfældet med den tredie idealtype kommer denne 
relatering til syne i inddragelsen af værdiideen om målrationaliteten, som er afgørende for både Webers teoridannelse generelt og også for hans opfattelse af konstitution og udvikling af den vesterlandske kulturvirkelighed. Her hedder det f.eks. at man må regne sådanne forhold for førkapitalistiske, i hvilke »den rationelle virksomhedsmæssige kapitalvalorisering og den rationelle kapitalistiske arbejdsorganisation endnu ikke er blevet herskende magter for orienteringen af den økonomiske handlen« (PE 43/32). »Rationalitet « betyder i sådanne sammenhænge frem for alt beregnelighed af følger ved indsatsen af bestemte midler for mål, her: virksomhedsmål. »Rationel « var dermed virksomhedskalkulationen, bogføringen, gevinst- og tabsberegningen og andre symptomer på kapitalistisk regnskabsmæssighed (jvf. PE 4f, PE 61/5f, 44).

De aspekter af en strukturtype »kapitalisme«, som jeg har trukket frem, lader sig ikke simpelt underordne som et forbigående motiv i en fremstilling af den opkommende borgerlige ordning, der ubetvivleligt er koncentreret omkring den protestantiske etos. Thi Weber vil med sin undersøgelse vise, »om og hvorvidt religiøse indflydelser har været medvirkende i den kvalitative prægning og den kvantitative ekspansion af denne ånd ud over verden og hvilke konkrete sider af den på kapitalistisk basis beroende kultur, der kan føres tilbage til dem « (PE 83/54). Helt uden for enhver tvivl lader Weber her kultur bero på en kapitalistisk basis, og hvad skulle der være ment med denne basis andet end bestemmelser, som udgør strukturtypen? Hvad angår mit første spørgsmål om fikseringen af den weberske tænkning på ideer og tænkemåder, må der altså $\mathrm{i}$ besvarelsen være plads for differentieringen. Ingen vil med alvor påstå, at Weber havde til hensigt at sprænge rammerne af sin egen metologi. Denne styrer ham uden tvivl ind mod kulturværdi-ideer såvel i antagelserne om konstitutionen af hverdagsverdenen som også i idealtypedannelsen. Men protestantismetesen arbejder ikke kun med to store overbygningstyper (I: katolsk traditionalisme; II: kapitalistisk ånd), den arbejder også med en yderligere strukturtype, som først fylder begrebet om »kapitalismen« ud. Og videre: Bestemmelsen af forholdet mellem de tre typer forekommer mig at vejlede den egentlige konceptualisering af den borgerlige udviklingsproces hos Weber - hvordan så end accenterne også måtte ligge. Strukturen af denne konceptualisering skal kort sammenfattes:

Weber sætter »traditionalisme « og »kapitalistisk ånd « i tre grundrelationer til hinanden: 1) Forholdet mellem delvist til modsætning tilspidsede forskelle; 2) Relationen mellem typerne som en historisk følge af type II efter type I; 3) Voksende empirisk gennemsætning af den anden type overfor 
den første (»fremhersken«). Samtidig må der imidlertid også tages hensyn til arten af deres relateringer til strukturtypen:

1) »Adækvans « betegner hos Weber den grundrelation, hvori den protestantiske etik som den kapitalistiske ånds tidlige form skal stå i forhold til den »kapitalistiske basis« (jvf. ovenfor). Thi en økonomis »kapitalistiske form « og den ånd, hvori denne $\varnothing$ konomi føres, står ganske vist generelt $\mathrm{i}$ et forhold af 'adækvat' sammenhæng, men ikke i en 'lovmæssig' afhængighed af hinanden« (PE 49/37). Med »adækvans « støder vi på endnu et af de sværeste begreber i den weberske teori. Hvis man ville undersøge disse bestemmelser i detailler, så måtte man faktisk, som Turner/ Factor nylig har gjort $\operatorname{det}^{7}$, efterspore den daværende retsvidenskabelige diskussions indflydelse på idealtypelæren i Tyskland. På det citerede sted bliver begrebet imidlertid mest anvendt for at sætte en økonomis »kapitalistiske form «, altså strukturtypen, i forhold til »kulturen «, altså overbygningstypen II. »Adækvans « skal, som Weber siger (PE 83/54), udtrykke eksistensen af et »åndeligt slægtskab « mellem indholdet i den asketiske protestantisme og den »materielle«, altså strukturelle side af den kapitalistiske samfundsorden. Efter alt at dømme henviser »åndeligt slægtskab« til det samme indlysende forhold: Den objektive proces af kapitalistisk reproduktion havde næppe kunnet finde udbredelse og varighed, hvis der ikke også fandtes struktur-adækvate værdiideer, som var inkorporeret i motiverne og tænkemåderne hos de struktur- og kulturbetydende grupperinger, hvis ikke hos flertallet af individer i det hele taget. En strukturel adækvat etos henviser således til hverdagsmæssigt anerkendte og/eller inderliggjorte værdiideer, som for det enkelte subjekt gør udførelsen af de for den strukturelle organisation formålstjenlige handlinger til selvfølgeligheder eller sågar pligter. Mistanken om, at en weberianer allerede hermed skulle være kørt fast i en borgerlig værdikonservatisme, rammer naturligvis lige i den blå luft. Det vil være let at modgå en sådan mistanke med henvisninger til Webers overvejelser om den fundamentale omvæltning af kulturværdiideer samt med den indsigt, at den weberske logik og metodologi ikke i sig selv giver grunde, der afskærer blikket fra alternativer til en gennemsat »adækvat etos «. »Adækvans « fører altså i sidste ende til området for undersøgelser af socialkarakterer eller, som Weber siger, »folkekarakterer $\ll$.

2) Helt konsekvent måtte »meningsdiskrepans« (Sinndiskrepanz) så anses for den grundrelation, der kendetegner traditionalismens forhold til

7. St. P. Turner/R.A. Factor: Objektive possibility and Adequate causation in Webers Metodological writings, in: The sociological Review 29, nr. 1, 1981, s. 5 ff. 
strukturtypen. Weber vælger ikke dette begreb. Men den traditionalistiske etos bliver af ham ikke kun bragt i forhold til den asketiske protestantisme; der findes derudover en række argumenter, som skal klargøre den katolske $\varnothing$ konomiske etiks manglende overensstemmelse med den tilblivende kapitalismes strukturelle organisation.

3) Bemærkelsesværdig finder jeg under alle omstændigheder den ejendommelige logiske status, som Weber vil tilskrive adækvansrelationen. »Adækvans « skal skelnes fra »lovmæssig afhængighed « (jvf. ovenfor). Som jeg ser det, har Weber på dette sted til hensigt at foretage afgrænsninger i to retninger:

a) På den ene side vender han sig mod vulgærmarxismen, som tyder ideer i en énsidig kausal afhængighed af den strukturelle basis. Naturligvis er også Weber bekendt med det forhold, at der fra det samfundsmæssige heles organisationsprincipper udgår kausale indvirkninger på hvert enkelt subjekts tænkning og handling. »Den nuværende kapitalistiske samfundsorden er et uhyre kosmos, som den enkelte er født ind i og som for den enkelte, i det mindste som enkelt, er givet som et faktisk uforanderligt bur, som han må leve i« (PE 37/30). Men den samlede konstellation af idealtyper kan ikke indsnaevres til kausalrelationen. Weber ville med rette gå imod enhver $\varnothing$ konomistisk subjektteori, hvor tænkningen og handlingen hos de enkelte personer (f.eks. som karaktermasker) i ekstreme tilfælde udelukkende behandles som logisk implikation af sætningerne om reproduktionskredsløbet og dets stadier.

b) Omvendt kan Webers tænkning heller ikke forenes med den type ansatser, som mange fortolkere mærkværdigvis ellers får ud af hans protestantismetese, dvs. alle forsøgene på at forklare opståelsen af sociale systemer som kapitalismen alene ud fra virkningen af ideer og tænkemåder. En logisk kirurg, f.eks. en sprogfilosof fra Oxford, kunne sikkert påpege den mangelfulde logiske struktur i adækvansbegrebets mellemstilling hos Weber. Er meningen med dette begreb at udtrykke en funktionalitet, der er forskellig fra kausalitet; er der tale om nødvendige, men ikke tilstrækkelige betingelser for strukturforhold? Drejer det sig om en intentionalitet, der ikke kan føres tilbage til kausalitet? Eller om empiriske hypoteser af arten: Indholdene $\mathrm{a}, \mathrm{b}, \mathrm{c} \ldots \mathrm{n}$ i et bestemt etos kræver - $\mathrm{i}$ forhold til alternativer eller $\mathrm{i}$ forhold til et historisk tidligere orienteringssystem snarere strukturelle forhold af typen $\mathrm{k}$ ? - Jeg lader dette felt for videre efterforskning ligge.

4) På steder, hvor Weber for engangs skyld eksplicit behandler strukturtypen, bestemmer han den ikke bare tilfældigt som »kapitalistisk basis«, hvorpå kulturen beror (PE 83/54). Basis-overbygnings- 
relationen hører således også til bestemmelsen af forholdet mellem idealtyperne.

Der kan muligvis rejses tvivl om, hvorvidt de tre idealtyper i Webers behandlingen af protestantismetesen er dannet strengt efter reglerne $i$ hans metodologi. At jeg har forstærket undertoner og foretaget ændringer er mig klart, og at protestantismetesens angivelige krav på at have opdaget den afgørende faktor for kapitalismens opståen dermed er blevet uholdbart, har allerede Weber selv sagt. Det drejer sig for ham kun om de religiøse indholds medvirken i den kapitalistiske udvikling (PE 83/54). Under en kritisk teoridannelses synsvinkel taler imidlertid intet af dette mod den vægt, som kan tillægges det overgribende argumentationsforløb i Webers protestantismetese. Jeg tænker her ikke så meget på den ikke særlig strikte idealtypedannelse, men mere på den skitserede form for relationering af de tre typer. Denne skænker de religiøse doktriner og tænkemåder afg $\varnothing$ rende opmærksomhed i overensstemmelse med programmet. Men deres rolle bliver behandlet $\mathrm{i}$ en argumentationsramme, som fastholder muligheden og nødvendigheden af at skelne mellem strukturelle og kulturelle aspekter af den samfundsmæssige realitet, sågar i specifik betydning som en totalsamfundsmæssig reproduktionsproces med kernestrukturelle bestemmelser (»formelt frit arbejde «) i forhold til den »kultur« som hviler på dem. Følger man disse forudsætninger konsekvent, så har samtlige relationeringer deres fokus, sidste relationspunkt, "grund « $\mathrm{i}$ basisbestemmelser. Det gælder især for de subjektrelaterede udsagn. Alligevel holdes muligheden åben for at forfølge meget forskelligartede relationer til basis og momenterne indbyrdes uden at forfalde til den flade $\varnothing$ konomisme og vekselvirkningsmetaforernes hjælpeløshed. Derudover står hele argumentationsstrukturen i et godtgjort eller efterviseligt forhold til historiskempirisk materiale. ${ }^{8}$ Mange samfundsteoretikere arbejder bevidst eller implicit med grunddistinktioner mellem basis og overbygning, struktur og kultur, subjektive og objektive samfundsmæssige faktorer. Lige så mange betjener sig af disse distinktioner på den mest grovkornede måde og uden bevidsthed om karakteren af den relationering, som hersker mellem de momenter som de dermed opererer med. Konstellationen af idealtyperne i protestantismeteorien betyder for mig en artikulerbar og fleksibel argumentationsfigur omkring disse problemer - en argumentationsfigur, som tilmed forbliver åben overfor empirisk materiale.

Bliver Weber på denne måde modelleret om til marxist? Bestemt nej. Jeg har blot villet pointere og idealisere den særlige form for anknytning til

8. Noter om hvordan forklarende udsagn indgår i konstruktionen, må jeg forbeholde andre arbejder om »kontekstforklaringer«til forskel fra »konneksforklaringer«. 
marxistiske motiver ved udviklingen af protestantismetesen. At Webers teori, som er opbygget over den målrationelle adfærd som elementær handlen og som er udviklet i relation til værdier, er ganske anderledes centreret end den marxske, er allerede forlængst blevet klart. Weber eller Marx? Det er et spørgsmål, som ikke duer til andet end de rituelle distanceringsøvelser, som mange parter og kredse forlanger af den, som angiver de dimensioner, hvori sammenligningen skal finde sted. Hvad angår protestantismetesen, så forstår jeg idealtypekonstellationen som et frugtbart eksempel på bearbejdningen af problemer, som også marxister fortsat har tilbage at behandle. Men det er et eksempel, der imidlertid for subjekteoretiske erkendelsesinteresser har sin afgørende grænse der, hvor det drejer sig om »folkekarakteren «, dvs. der, hvor det mere vidtrækkende drejer sig om de socialstrukturelle forudsætninger for en subjektivitet, der er istand til en selvstændig deltagelse i omformningen af de socialstrukturelle forhold. I dette tilfælde forekommer det mig mere lovende at gribe tilbage til Hegel, som står meget nærmere Marx.

(litteraturliste fortsat fra side 50)

Lowi, Th.J., 1964: Ein neuer Bezugsrahmen für die Analyse von Machtstrukturen. Optrykt i: Narr, W.D., Offe, C. (Hrsg.), 1975: Wohlfahrtsstaat und Massenloylität, Köln/Berlin West

Mickler, O., 1981: Facharbeit im Wandel. Frankfurt/Main

Müller, W., 1973: Der Pluralismus - die Staatstheorie des Reformismus, i: Doeker, G., Steffani, W. (Hrsg.): Klassenjustiz und Pluralismus, Hamburg

Scharpf, F.W., 1974: Krisenpolitik, i: Oertzen, P.v., Ehmke, H., Ehrenberg, H. (Hrsg.): Thema: Wirtschaftspolitik, Bonn-Bad Godesberg

Scharpf, F.W., 1976: Wirtschafts- und Gesellschaftsstruktur in der Bundesrepublik Deutschland. Thesen zum Referat auf dem Kongress der IG Metall »Krise und Reform der Industriegesellschaft «, Manuskript

Schiller, K., 1968: Konjunkturpolitik auf dem Wege zu einer Affluent Society, i: Schwedler, R., Föhrenbach, W. (Hrsg.), Jahre der Wende. Karlsruhe

Shaiken, Harley, 1980: Neue Technologien und Organisation der Arbeit, i: Leviathan 2/1980 